\title{
Empowerment or repression? Opening up questions of identification and surveillance in Brazil through a case of 'identity fraud'
}

\author{
David Murakami Wood • Rodrigo Firmino
}

Received: 24 April 2009 /Accepted: 15 January 2010 /Published online: 20 February 2010

C) The Author(s) 2010. This article is published with open access at Springerlink.com

\begin{abstract}
A real but typical case of identity fraud is used to open up the complex web of identification systems in Brazil. It is argued that identification has two poles related to the nature of citizenship - repression and inclusion - and that reactions from citizens to new identification schemes can be attributed to how they view the purpose of the cards in these terms. In Brazil, a sense of inclusion and citizenship based on a fear of anonymity and exclusion predominates leading to widespread support amongst even critics of state activities. However, this may be undermined by the lack of state preparation for an information society, particularly the absence of meaningful data protection laws.
\end{abstract}

Keywords Brazil · Citizenship · Identification · Identity · Social inclusion · Surveillance

\section{Introduction}

In most modern nation-states, entering into a relationship with the state demands forms of identification of the person by the state (Dandeker 1990; Torpey 2000; Bauman 2004; Lyon 2009). This relationship is more or less voluntary depending on the state and on the subject of the relationship. In most advanced liberal democracies, the nature of identification is based on the nature of citizenship, and as Valentin Groebner (2007) has pointed out this connection between identification and citizenship only became more widespread in the Twentieth Century. Before this

D. Murakami Wood $(\bowtie)$

Queen's University, Kingston, Ontario, Canada

e-mail:dmw@queensu.ca

R. Firmino

Pontifícia Universidade Católica do Paraná / Pontifical Catholic University of Paraná (PUCPR),

Curitiba, PR, Brazil

e-mail: rodrigo.firmino@pucpr.br 
time, identification had been either for specific purposes or specific groups or classes of people, and most interactions depended on a more everyday knowledge of identity. However, as Zygmunt Bauman (2004) argues, "the nascent modern state... faced the need to evolve an order no longer reproduced by the well-settled and closely-knit "societies of mutual familiarity" (19). The kinds of identity based on personal knowledge and trust did not function in larger, more complex communities. However, the loss of an understood identity (however much this was already a social construct) means that "identification' becomes more important for the individuals desperately seeking a 'we' to which they may bid for access" (ibid, 24). In other words, forms of inclusive (and exclusive) citizenship, with identification systems to determine who belongs in and out, provide (at least partial) replacements for locality and class-based forms of community.

What is meant by citizenship is complex and varied but usually consists of some or all of the following: the ability of citizens to establish claims to entitlement, fundamental to most being a recourse to the law (to protect person and property), secondly the ability to cast a vote, and something that is generally more recent in most states, the right to some kind of support from the state (educational, medical, or financial). Conversely, citizenship also allows the state to acquire funds from citizens through direct or indirect taxation, to support the entitlements of citizens, and to maintain 'order'. In state-thinking, identification, as James C. Scott (1998) argues, has the general aim of increasing the 'legibility' of the citizen, to make the job of government easier and more efficient. Both Jane Caplan (2001) and Valentin Groebner (2007) also point out, the 'utopia' of early modern Prussian jurist and philosopher, Johann Gottlieb Fichte, was no only that individuals should be identifiable but also that 'no-one must remain unknown to the police' (Fichte 1796 in Groebner 2007: 229). Of course the state is far from simply 'the police', but it draws attention to the question of the boundaries of citizenship - and in particular of what it is about the citizen that is to be known, in other words of the question of privacy, and particularly of its limits. Danilo Doneda (2000) points out the importance of defining the boundaries in the balance between citizenship and the risk of privacy loss. He uses the Human Genome Project to exemplify the difficulty of finding such limits between what could be potentially good for a variety of medical research fields but also more dangerous in terms of association of identity and identification to specific (and immutable) genetic code profiles. One can make similar argument about the use of biometric technologies for identification.

However other boundaries are also being transgressed. As Nikolas Rose (1999) persuasively argued, these forms of identification are no longer just a product of state activity, they also depend on and are enacted in relationships with private entities: corporations - both as employees and as consumers - and other citizens. Further, David Lyon (2009) has claimed recently that we must reconsider the conceptualisation of identification to take into account the role of the private sector in providing the means of identification, and often in promoting and justifying certain forms of identification technology, particularly so-called 'smart cards' and advanced biometrics, and in pushing global standardisation and interoperability. This is where identification starts to meld with surveillance, as ID is used to fix people in increasingly shared banks of information on individuals and groups. The right to privacy, for example, acquires new and emblematic characteristics when, as Doneda 
(2006b: 5) argues, we seem to be witnessing the transformation of what has been declared by the North-American Judge Thomas Cooley in the 19th Century as the "right to be let alone" into something like the "right to control the use made by others of information about me". In other words, by posing the privacy problem as one of control, not only is the identification-surveillance connection reinforced and privacy becomes something rather more malleable and fluid. We would argue that the combination of surveillance and identification is one key aspect of what constitutes a 'surveillance society' (Lyon 2001; Murakami Wood et al. 2006) or indeed what Deleuze (1990) called a 'control society'. There is in this context, a need to consider the political economy, not just the sociology, of identification and surveillance (Lyon 2009).

The caring, inclusive, rights-based society and the repressive, control society are the two ends of the spectrum of citizenship, identification and surveillance and this has been at the heart of the enterprise of Surveillance Studies (see Lyon 2007). As Bauman (2004: 32) astutely remarks "in our world of 'individualization', identities are mixed blessings. They vacillate between a dream and a nightmare, and there is no telling when one will turn into another". However, even in the era of globalisation, the distinctiveness of national trajectories of identification remains important. Not every nation-state has the same history of identification, and not every nation has the same reasons for establishing, maintaining or changing the identification systems that they use. Historically, identification has been used for both purposes (see the range identified in Caplan and Torpey 2001), and a variety of identification systems and purposes can continue to be seen worldwide (Bennett and Lyon 2008). General and generic arguments about surveillance society do not serve us unless they are made with some greater awareness of the interactions of history, place and culture (Murakami Wood 2009). States can be more or less inclusive and repressive, the specifics are important and the caring end of the spectrumsurveillance that relates to welfare, health, education, social inclusion, and even empowerment, for example-still needs greater emphasis.

In this paper, we examine the case of Brazil. We use a story of one citizen's growing awareness of the importance of his multiple forms of identification that resulted from his experience of identity fraud. We are not going to elaborate much on identity fraud beyond the story rather to use it, as has the protagonist, to discover more about the bureaucracy of state-citizen relationships in Brazil. The paper also draws on participant observation of interactions around identification, everyday conversations with Brazilians, and several interviews conducted in Curitiba, São Paulo, Brasília and Rio de Janeiro with experts, bureaucrats and politicians between January and April 2009.

The argument of the paper is that there are two broad and opposing categories of fears that drive citizens' reactions to state identification schemes, which map closely to the two poles of inclusion and repression. The first is the one that is more familiar in states like the USA and the UK, which is the nightmare of order, in which privacy is destroyed as the state becomes over-intrusive and controlling. However the other is the fear of exclusion, in which the citizens' greatest concern is to be unknown and therefore potentially to disappear as the victim of arbitrary forces. We argue that in the Brazilian case, the latter is almost universal, and that the fear of anonymity and being 'lost' is far stronger than any concern about surveillance or control, and that 
this is far stronger when it comes to the relationship of identification to social class. Here in fact, it is the poorest in Brazil-those who are at the greatest risk of such 'disappearance' - who are most likely to favour state identification schemes as mechanisms of inclusion. However, throughout Brazilian society, this existential fear, which rests in the nature of Brazilian citizenship, provides a strong basis for support for better state identification. This calls into question universalising theories of the control society of surveillance society, but rather than dismiss them entirely, it leads us to argue for subtle adjustments, arguing for the existence of multiple surveillance societies, with distinct contextual nuances and levels of intrusion as well as different concerns regarding privacy, anonymity and control.

\section{Identification, identity and fraud: the case of an ordinary Brazilian citizen}

On a relaxing Sunday afternoon in September 2006, Carlos da Silva, ${ }^{1}$ a 30 something middle-class professional living in the state of São Paulo, received a call from a telephone company, "TelecomX", asking for his name and CPF (registry of physical persons), advising him that he had a debt with them for some calls using their prefix of a telephone account in the state of Santa Catarina, in the South of Brazil. This was puzzling to Carlos, as at that time, he had never been in to the more southerly parts of the country.

It was also unusual to receive any call from a corporation on a Sunday, and as Brazilians are always on the alert for someone trying to take advantage of them, Carlos immediately refused to confirm his data as he suspected that it might be one of the ways some malicious people might use to acquire his personal details. After getting the company's registered toll-free number, Carlos explained the situation trying to check the veracity of the story, which he found, unfortunately to be true. The company was trying to assess whether Carlos recognized these calls made in another state from an account in his name, and thus to ask whether he recognized the debt. He was given the option of contesting the debt and the origins of this account, in order to clear his name and close the debts, which he of course did.

Then they informed Carlos that the telephone account was registered to another company, "TelecomY", and that he would need to call them directly in order to close the account and clear any possible debts. These debts also turned out to be all too real, and Carlos had to go through a similar process of contesting them with callcentre workers in order to discover that he had, in fact, two different accounts opened on his behalf, one in the state of Santa Catarina and the other in the state of Paraná (where Carlos now lives, but where he had never been at that time).

All these issues were apparently resolved in less than forty-eight hours by the companies' credit and customer departments. Carlos's name was not registered as a debt-defaulter with any credit-referencing agency in these cases, and he had not paid too much attention to the situation as a whole because everything was so easily resolved.

\footnotetext{
${ }^{1}$ For obvious reasons, all personal details have been altered, so we have used fictional names for people and institutions.
} 
In the mid-2007, Carlos moved to Curitiba, capital of the state of Paraná, to take up a new job. There are different regional mobile telephone prefixes across Brazil and while trying to transfer his mobile account he was refused the registration by the mobile company, with the argument that his name was appearing on one of the credit protection systems as a known-debtor. ${ }^{2}$ As a good-payer who pays all bills promptly, he was surprised by the news and forced to do the transfer using his wife's account. Thus, besides feeling embarrassed in front of the attendant, he had to have his own mobile phone registered to his wife, which although it was not a problem in itself, it added to the general confusion.

The next step then, for Carlos, was to approach the credit-referencing agencies to find out what debts 'he' had and with which companies. By this stage, Carlos was not surprised to find out that apparently he had had two mobile phone accounts with yet another mobile company, "TelecomZ", in the city of Barbacena in the state of Minas Gerais, far away from where he lived and another place to which he had never been. After going through a nightmare of transferred and unresolved phone calls to different call-centre operatives and departments, TelecomZ informed him that the accounts had been opened sometime around September 2006. Carlos had no more problem than before in cancelling these accounts and debts, and the call-centre operator told him that complaints department was used to this kind of situation because of the number of frauds they had to deal with. Carlos began to realize that he did not even have to explain his case in any detail as he was seemingly just one more victim calling to contest improper debts. They already knew everything he had to say. And they were very quick on taking his name off the credit-reference agency lists with apologies, as further embarrassments could lead them being taken to court.

By this time, however, Carlos had become a lot more concerned with the situation of his identity documents. As it is usually impossible to open mobile telephone accounts in Brazil without several forms of ID (for reasons we will come back to later), it was clear that he had become a victim of effective and systematic identification fraud. Thus, he decided to take the situation a lot more seriously and went to the police to report what had happened to him. He went to a special unit of the Civil Police charged with dealing with crimes of fraud, ${ }^{3}$ and reported all stories including the cases he originally found out back in 2006. The police officer instructed him to call TelecomZ and ask them to provide all legal documents and contracts used to open the two accounts on his behalf.

Surprisingly enough, the call-centre operators told him that no documents were physically shown or contracts signed in order to open the account and buy the mobile phone. Everything was carried out by telephone, so the fraudster had only given them Carlos's ID numbers and personal details, and opted to receive the phone

\footnotetext{
${ }^{2}$ As this transfer operation was administratively treated by the mobile company as the opening of a new account, they had to run credit checks over Carlos' name through different online credit protection systems.

${ }^{3}$ The system of police in Brazil is now quite complex, but originally followed the European model of an armed 'gendarmerie', focused on enforcement, known as the Polícia Militar (Military Police) and a separate 'detective' force, the Polícia Civil (Civil Police). These police are based in the 27 separate states that make up the Brazilian federation. More recently, a Policia Federal (Federal Police) has been set up to deal with national-level criminal activity like smuggling and large-scale fraud and corruption. In many cities, mayors have also created Guarda Municipal (Municipal Guard), a less well-trained but supposedly more 'civic' force to deal with neighbourhood issues.
} 
by post. It was very frustrating to Carlos to see that the fraudsters were having much less trouble using his details to open accounts and buy things than he was in trying to prove who he was and clear his false debts and his good name.

At the police station, the officer tried to calm Carlos by telling him how common these crimes are, and that his case was not even close to the worse scenarios he had encountered, like exactly copied identification documents with altered pictures and fingerprints, and people being arrested because of crimes committed by other people carrying their cloned IDs. Then he advised Carlos on how to deal with these situations in the future: first and more importantly, he should carry the police report with him at all times, at least to give himself the benefit of the doubt in case he was mistaken as a possible fraudster or criminal. Secondly, the officer offered him two options: Carlos could either report that he had been a victim of fraud with commercial and credit-referencing agencies - which would make it increasingly more difficult for him to carry out ordinary transactions, and also that it would become more and more difficult to prove that he really was who he said he was (but of course, even more so for the fraudsters) — or, alternatively, to run regular checks with the credit-referencing agencies in order to see if there were something wrongly associated with his name, and in this case, to go through all the same 'cleaning' procedures all over again. ${ }^{4}$

Carlos opted for the latter, and now lives well aware of the risks of having his identification numbers - but not necessarily the actual documents, there has been no direct evidence of that yet — copied and used all over Brazil. He feels like his IDs are just 'out there' circulating on lists bought and sold between criminals. And of course, Carlos is not comfortable about that and does not even know when and how often it will be that he will have to prove who he is, even if he just wants to rent a DVD or buy a mobile phone.

\section{The Brazilian web of identification systems}

In every nation-state, there are particular things that citizens take for granted, more than anything else. These things are not always the same. For some, it is democracy, or the free market, or the welfare state. In Brazil, one of these things that is very deeply embedded in the way of life so that people do not even think about it very much, is the prevalence of the need for identification, or rather, the overlapping system of many different tokens of identification attached to every single citizen from the poorest to the richest, in many different ways, for multiple purposes. Brazil is certainly not unique in this way, but it is a particularly clear example of society where a large percentage of everyday interactions between citizen and state, and citizens and the private sector, and even sometimes between citizens themselves, require the presentation of either identification numbers or tokens of identification, and often more than one on each occasion.

\footnotetext{
${ }^{4}$ Several authors have noted the way in which identity fraud and theft discourses and remedial processes have clearly disciplinary functions, that responsibilize the citizen (see e.g. Caeton 2007; Marron 2008; Whitson and Haggerty 2008; Monahan 2009).
} 
The question of why mobile telephony is so prominent in this story is one such example. We had been told by many people that so much information was collected by phone companies because of laws, requested by the Federal Police, which would allow them to identify and monitor the communications by drug barons in federal prisons. It was said that they could have blocked the signals from prisons, but instead the information from monitoring was considered to be so valuable in the provision of evidence that a detailed nationwide system of registration of mobile telephone accounts was considered preferable to blocking signals, however intrusive on innocent citizen's lives. This sounded like an implausible conspiracy theory, but it was confirmed in interview with the Federal Police. ${ }^{5}$ Any interaction involving mobile telephony - purchasing handsets or SIM cards, changing numbers etc.-is therefore subject to quite extensive bureaucratic identification and record-keeping procedures (see below).

The first token of identification a citizen will receive is the Birth Certificate (Certidão de Nascimento), which for many years is the only official paper that a person will have. This in itself is not something that can be taken for granted. The requirement to register births (and marriages and deaths) was only introduced in 1939 as part of the Estado Novo dictatorship of Getúlio Vargas and despite the lack of places to register births especially in rural and poor or informal communities, without the birth certificate none of the other papers needed later in life could be issued. Systems for retrospective registration were introduced but even after reforms, these still required procedures involving lawyers, courts, witnesses and other corroborating papers (see Fischer 2008).

Then there are various papers associated with school-which are too numerous and specific to be listed here. As soon as Brazilians become teenagers and there is any kind of need to prove to officials and shops who they are (so, as a means of governmental identification control as to fill a police report or as a credit guarantee while registering with the local DVD rental shop), they are issued with what is known as the nationwide Identity Card (Carteira de Identidade) which is more generally referred to as the RG (Registro Geral, the General Registry, the database, to which the card is the link). The RG is supposed to be taken wherever a Brazilian goes. Although it is often asserted that ID cards in Brazil are also a product of the Estado Novo, the origins of the RG actually pre-date this regime. As Brodwyn Fischer (2008) observes, they were (and are) local rather than national, and in Rio de Janeiro for example, they grew out of police identification initiatives that were intended to help them identify criminals. The Rio Military Police Identification Service remains at the forefront of ID technology in Brazil. And the cards were far from compulsory. The foundational law of 1923 actually made it quite difficult to obtain an ID card, requiring such pre-existing forms of proof of identity as a letter from the police, verifiable evidence of parents' identity, proof of date and place of birth (which as we have seen, few people would have had at this point), and more (Fischer 2008). These original ID cards were a mark of a special form of privileged

\footnotetext{
${ }^{5}$ Interview with Delegado Romulo Berredo of the Policia Federal, Brasilia, February 2009. The question of why the police really monitor the calls of drug traffickers remains open, with many informants arguing that corruption (based on the ability to know when and where large drug deliveries were taking place) was the real reason...
} 


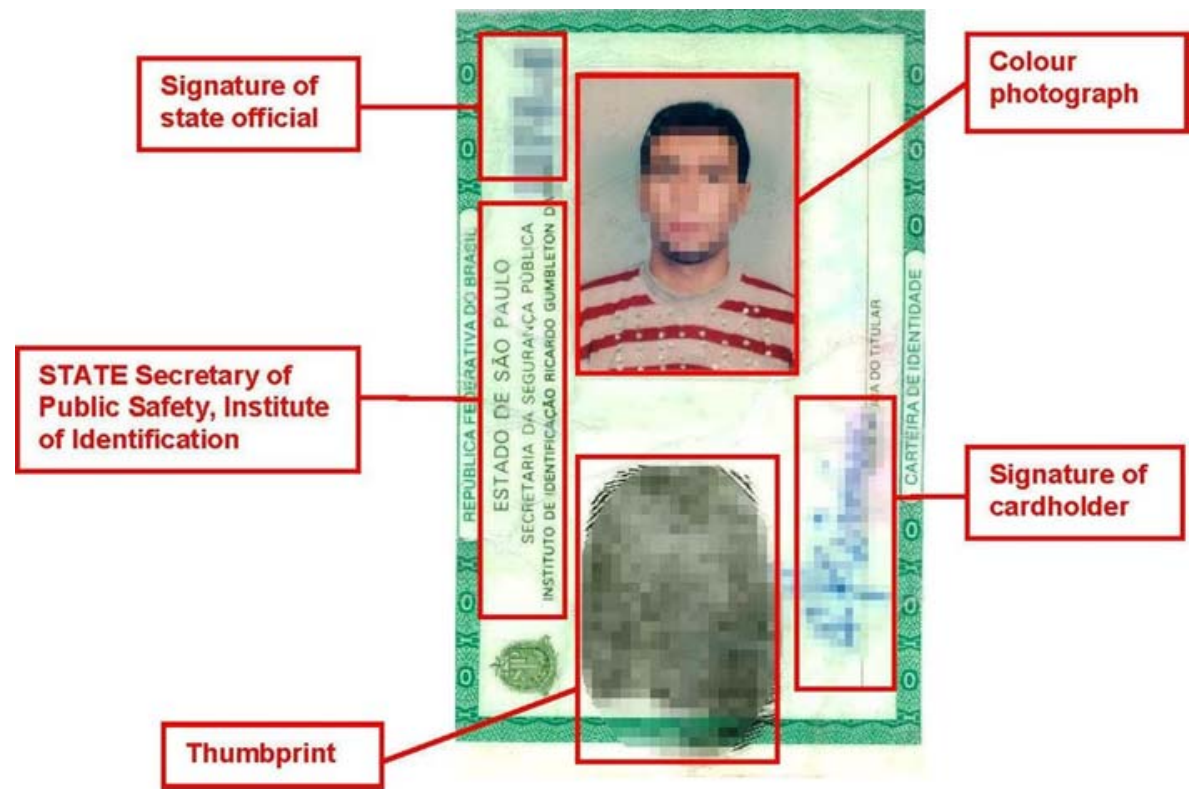

Fig. 12008 Brazilian Carteira de Identidade (Front) (Source: Authors)

inclusion as a specific kind of economic actor, not a tool of generalised discipline or control.

Even as it is being replaced (see below), for most people, the current RG card (see Figs. 1 and 2 below) is a double-sided piece of thick paper, just larger than a credit card. It is oriented vertically at the front and horizontally at the back. It cross-

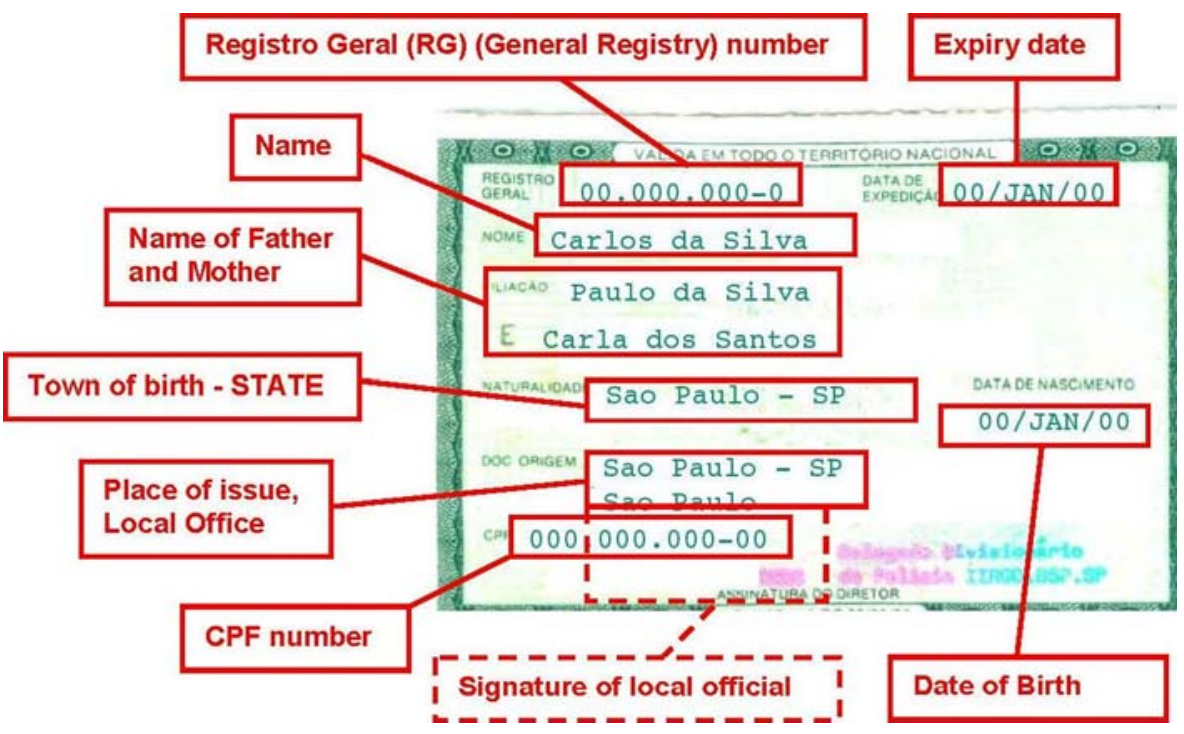

Fig. 22008 Brazilian Carteira de Identidade (Back) (Source: Authors) 
references the Registry of Physical Persons (CPF or Cadastro de Pessoas Físicas) to which we will come back later-and also birth certification (it lists the full names of both mother and father and city and state of origin). It is issued at state, rather than federal level.

The RG is intended to be a comprehensive identification method, but in real life it does not work like this and Brazilians pay little attention to this document. As they grow older and adult responsibilities become more important, they are issued a unique number which is demanded for almost every single transaction they carry out in the country. From progress through school and college to opening a bank account, or buying a mobile phone and - especially - paying taxes, in other words virtually any transaction someone gets involved with in normal life, they need what is called literally the Registry of Physical Persons (CPF) card, but basically a 'taxpayer's card'. The CPF is the current descendant of the carteira profissional (CP) (often called carteira de trablaho (CT) or Labour Card) introduced in 1932 and then extended and detailed in the 1934 Consolidação das Leis do Trabalho (Consolidation of Labour Laws, or CLT). As the early local ID cards also did in a less direct way through the onerous evidential requirements needed to obtain them, the $\mathrm{CP} / \mathrm{CT}$ created a clear division between some who were included and others who were excluded. In this case, the divide was between those who were defined as 'workers' and others. It would be more accurate in political economic terms to define this as a division between formal and informal workers, but here, the term 'workers' had a specific meaning in the terms of the law. This division has nominally been erased from the current CPF, although in many ways the division that the $\mathrm{CPF}$ creates is a more profound one and one that was always just under the surface of the $\mathrm{CP} / \mathrm{CT}$ system: a division not around labour, or even citizenship, but something more fundamental, personhood. As the label of worker came to acquire social value, those that were 'not workers' were correspondingly devalued and their status as equal citizens and equal people was eroded. The fear that one could become less than a person - someone unrecognised and anonymous - remains the key fear driving support for identification schemes in Brazil.

As taxation of persons and companies/institutions are made separately in Brazil, there is also a different registration number for what in the Portuguese tradition is referred to as a Juridical Person, or Cadastro Nacional de Pessoas Jurídicas (CNPJ). Receita Federal (Brazil's IRS or Inland Revenue) runs separate taxation systems for persons and companies/institutions, meaning that every person (officially registered as a taxpayer) has a CPF while every company or institution has a CNPJ. The actual CPF document is a blue plastic card like old-style credit cards, which also has a machine-readable magnetic strip on the back (Fig. 3).

Many other types of identification schemes run parallel to RG and CPF, such as: the Carteira Nacional de Habiliação (driving license), voter IDs, military service certificates, and so on. For regular commercial transactions Brazilians are usually required to produce at least the $\mathrm{RG}, \mathrm{CPF}$ and a proof of address (which can be any kind of official bill). In some specific kinds of registration processes, Brazilians need to show even their voter ID (together with the proof that they voted in the last election, as this is compulsory in Brazil) and military service certificate (for males only). There is a separate system of identification for foreign residents, the Registro Nacional de Estrangeiros.

The driving license which, despite its name, is issued at state rather than nationallevel differs in colour and format from state-to-state, having, however, pretty much 


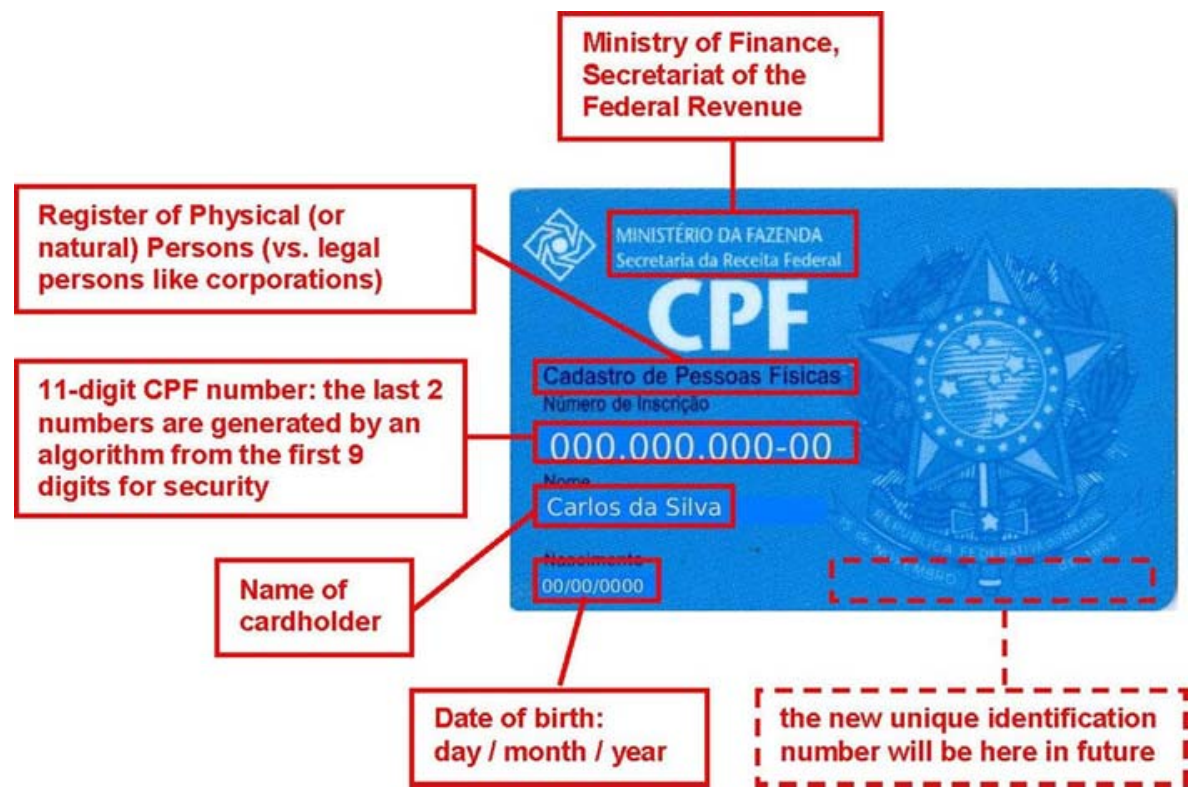

Fig. 32008 Brazilian Cadastro de Pessoas Físicas card (Source: Authors)

the same level of information and cross-identification with other forms of ID. Figure 4 shows the one from Paraná, which is a paper usually folded in half horizontally. It is specifically forbidden to laminate it.

One final form of identification is proving to be very important, especially for those marginalised by poverty and not possessing some of the other forms of identification. This is the Programa Bolsa Familia (PBF, or Family Grant Program), one of the cornerstones of the socially progressive politics of the current Brazilian government. ${ }^{6}$ The PBF was set up by President Luiz Inácio Lula da Silva ('Lula') during his first administration to unify, simplify and extend the previous multiple, often contradictory and difficult to administer number of social programs. Such programs again originated during the Estado Novo, however the Abono Familia created by the 1941 Lei de Familia was, like many of the other programs of the time, strongly symbolic and difficult to claim in practice without a relatively high degree of literacy and knowledge. This led to a very small take-up related to need, and in any case favoured those already in work who were able, again, to show who they were (Perlmann 1976; Fischer 2008). Once again, the system was one which made a clear division and a privileged inclusion.

The PBF in contrast provides a very simple, small but direct payment to families with children, for each child, provided that the children go to school and have medical check-ups. Underlying the entitlement is massive compulsory collection of personal information through the Cadastro Único para Programas Sociais (CadÚnico, or Single Register for Social Programs). ${ }^{7}$ This is, of course, a database

\footnotetext{
$\overline{{ }^{6} \text { http://www.mds.gov.br/bolsafamilia/. }}$

${ }^{7}$ http://www.mds.gov.br/bolsafamilia/o_programa_bolsa_familia/cadastro_unico/o-que-e-1.
} 


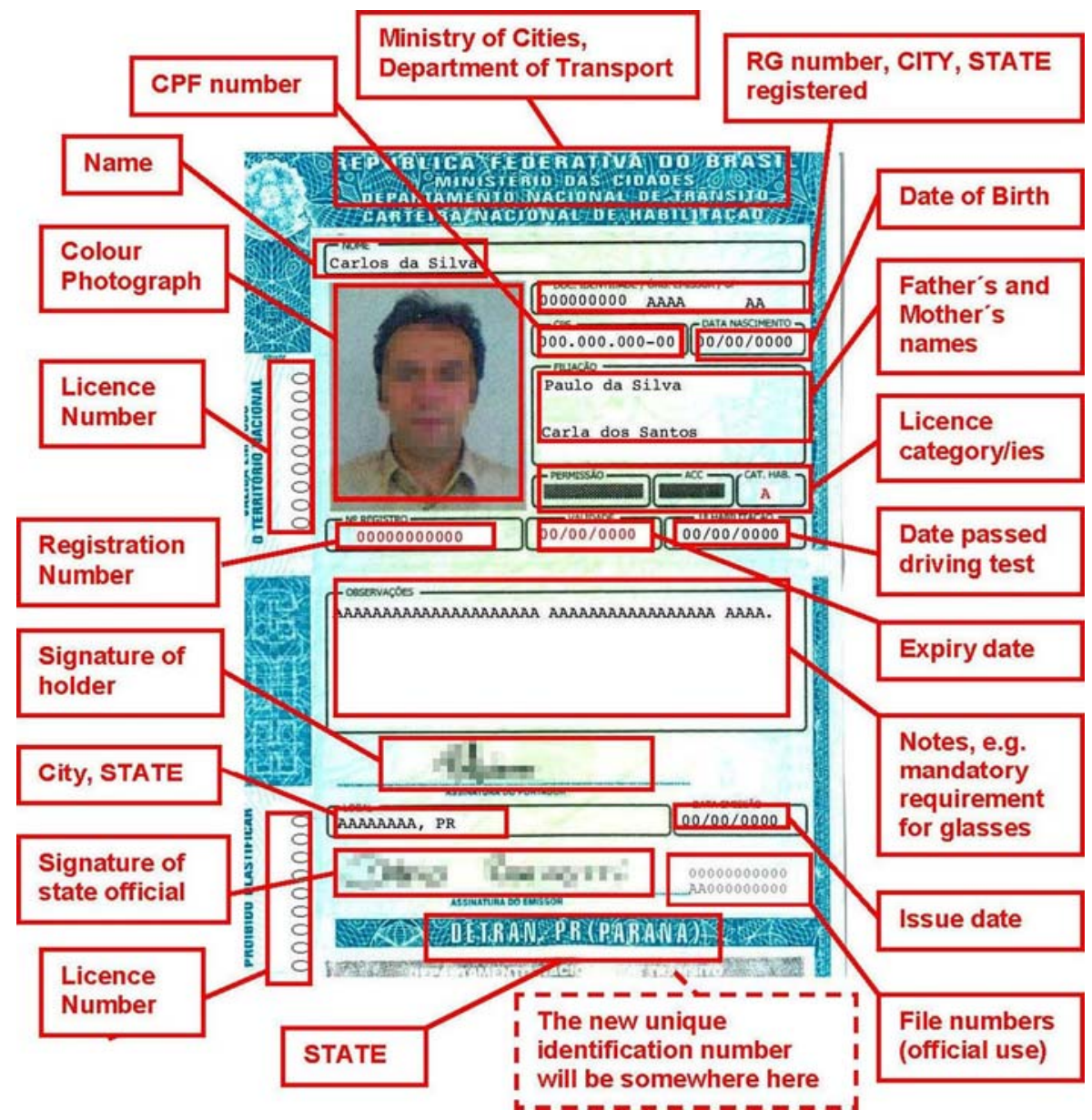

Fig. 4 Carteira Nacional de Habiliação (Source: Authors)

system which, as the CadÚnico website states, "funciona como um instrumento de identificação e caracterização socioeconômica das famílias brasileiras" ("functions as a means of identification and socioeconomic characterization of Brazilian families"). Like most Brazilian state financial systems, CadÚnico is operated through the federal bank, the Caixa Econômica Federal (CAIXA). The CadÚnico database is founded on "um número de identificação social (NIS) de caráter único, pessoal e intransferível" ("a unique, personal and non-transferable Social Identification Number or NIS").

Entitlement to this program is demonstrated with yet another card, the patriotic yellow and green Cartão PBF (Fig. 5). Like the CPF card, which-apart from colour - it very much resembles, this is a magnetic strip card rather than a smart card, and is required for all transactions involving the PBF. Also like the CPF, but unlike many other forms of Brazilian ID, it has nothing more than the name of the recipient and the CadÚnico number printed on it. In this case the recipient is generally the mother of the children being claimed for, a progressive and practical measure shared with other contemporary family entitlement programs in Brazil. 


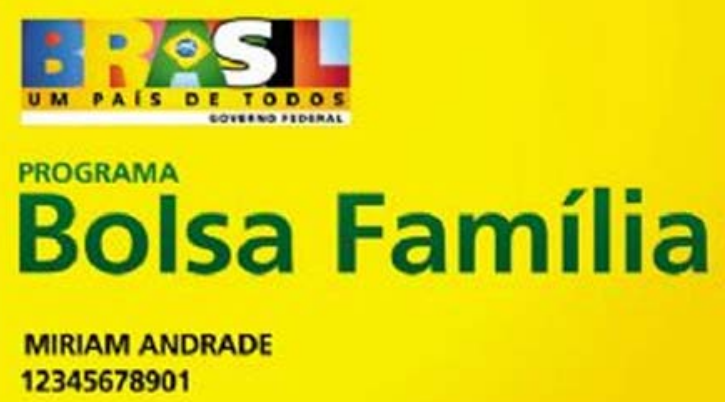

Fig. 5 Brazilian Carteira Programa Bolsa Familia (Source: Government of Brazil)

Given the previous generations of family programs which followed the precedent set by the 1941 law, it is important to note that many of those entitled to the PBF, and consequently to receive the PBF card, do not have to have $\mathrm{CPF}, \mathrm{RG}$ or other tokens of identification. In many, but not all cases, these people are not tax payers or do not take part in many transactions that most people from higher social classes would find ordinary (they may not have bank accounts or mobile phones, for example). This makes the program accessible but it is undeniable that, apart from being a social program, the PBF is also a way for the government to acquire personal details and identify people normally excluded from regular forms of identification and data sorting. The key question, and one which we shall attempt to answer in the concluding section, is whether this increase in surveillance is actually any kind of social or political problem.

\section{The insecurity of identification in Brazil}

Despite these multiple forms of identification which one needs for every transaction with the state and many private organisations too, they are highly insecure. What is more, as we have seen, all these are not just numbers in a database somewhere but material documents, or tokens, in their own right and on each token there is a lot of cross-identification. One example is that every personal cheque has printed on it not only the usual information (bank name and address, bank sort code, account holder name and account number), but also has the CPF number and the RG number. This must be utter joy to fraudsters and identity thieves. It is probably lucky that personal cheques are not widely accepted.

The CPF card also has the name and date of birth, and the CPF number is ubiquitous, appearing also on the RG card and the driving license. The latter has its own 11-digit registration number, but also has the RG number, name, and place and date of birth. What is even more interesting is that the RG card not only contains a photo and a thumbprint (the state database contains prints of all ten fingers and thumbs), but also the names of both parents. This means it can be related more easily to the birth certificate as well. This is reminiscent of the Japanese system which still prioritises the 
family above the individual in some ways (see: Murakami Wood et al. 2007) but there is no actual equivalent of the kouseki, the Japanese family register, for example.

The Brazilian driving license is a goldmine of personal information. Partly this is because the license had previously been intended to be a unifying piece of identification; a practice typical of 'autocentric' cultures as in the example of the USA, where the driving license is to all intents and purposes an ID system whether this is acknowledged or not. The Brazilian license contains all the information on both the CPF card and the RG card, and more. Following the issuing of the new Registro de Identidade Civil (RIC) cards, there will no longer be the necessity for the license to act as a de facto ID card, so it will be interesting to see if the quantity of information on these licenses will be reduced or, if not, what the justification will be for having this much easily readable personal information on one material token.

It is worth noting that the PBF card is exceptional in having such a limited amount of information on it. As we mentioned above, rather than being a result of some exceptional attention to the protection of the poorest families from fraud, this is in fact simply a recognition of the fact that so few of the very poor have CPF cards, having never worked in the formal economy or paid taxes. However the lack of visible information means that the PBF card in itself may not be enough to claim as a citizen would still need at least the RG card in addition to prove that they were the named holder of the PBF card.

It is this wealth of information which is taken that produces one means by which identification numbers flow into illicit channels. Jennifer Whitson and Kevin Haggerty (2008) have pointed to surveys by credit providers that show that a substantial majority of all identity frauds are the result of 'inside jobs', and in Brazil, with its highly bureaucratised citizen-state and citizen-corporation relationships, organisations store more valuable information on the individual than in most places even as the result of everyday transactions. For example, we observed the process of obtaining a mobile telephone in a major city in Brazil: the data demanded by the company included the RG, CPF and CNH numbers, full name, address, and date of birth. The payment details and credit card numbers were also taken to ensure payment. These were copied by hand onto a single paper form that was then stored in a simple filing cabinet. Photocopies of the relevant documents were also taken. In one place, in one file, after a single transaction, were practically all the details of a person, easily enough to obtain another mobile telephone account, another ID card, or open a bank account. And there are many such everyday transactions that result in the creation of such paper or electronic files of personal identification information. Indeed, this seems to be exactly the process that allowed our protagonist, Carlos da Silva, to fall victim to fraudsters.

There are two additional problems in Brazil. The first, as was pointed out in an interview by Danilo Doneda, Brazil's leading expert on data protection, ${ }^{8}$ is the almost complete absence of any data protection law other than a very vague citation to the right of data protection in general lines of the 1988 new Federal Constitution

\footnotetext{
${ }^{8}$ Conversation with Danilo Doneda, Curitiba, February 2009. Doneda was engaged by the Brazilian government to write a federal data protection law, but the Ministry of Justice seems to have curtailed further progress on this project at present. However, the presence of Brazilian government officials in Madrid may well signal a renewed effort in the direction of such a law.
} 
(Doneda 2006a) and the lack of any regulatory body for data protection. Indeed the Madrid meeting of international Privacy and Data Protection Commissioners in 2009 appears to be the first one that any official Brazilian delegation has attended. As with many South American countries, the principle of habeas data is recognised however this is a right that requires a legal challenge to enforce, which puts it effectively beyond the category or rights that are generally accessible. This makes Brazil almost unique amongst democratic countries. And interviews showed that senior police officers, for example, whilst recognising the huge problem of identity fraud, saw the solution as purely a technical one requiring a new higher technology form of identification, not new legal protections for the rights of citizens. ${ }^{9}$ The creation of new databases brings with it new duties and new potential problems of data-handling, yet the response of one interviewee was simply that if government organisations did not carry out their duties correctly then they would lose the trust of the people. ${ }^{10}$ The problem with this argument is that it would have to be the case that citizens already had some degree of trust in the state, however no-one interviewed from non-government organisations, or who were simple private citizens demonstrated such trust (and particularly not in the police). One exception to the lack of concern over data protection is, surprisingly the PBF. The government has set up an Observatório de Boas Práticas na Gestão do Programa Bolsa Familia (Observatory for Best Practice in the Management of the $\mathrm{PBF}$ ), which has a whole raft of measures to safeguard and protect the data, correct errors and so on-in other words, data protection. ${ }^{11}$

The second factor is that the system of enrolment and issuing of identification documents at present is chaotic and corrupt. Despite the fact that RG cards are valid, as is stated on the top of the back, 'in all the territory of the nation', Brazil being a federation, they are issued by the individual Brazilian states, which allows anyone with any other form of ID to get a state RG card in each different state, should they wish too. It is thus fairly easy to acquire 27 different identities in Brazil at present. This may not present any particular concern in itself, but in a country of gang-related violence and endemic corruption, it makes finding the perpetrators of such crimes very difficult, and indeed facilitates the latter.

Whilst it may be easy to acquire an RG card, it is less easy to acquire a CPF number, also required for many other government transactions, and it is a major disaster if the citizen loses the card, or if for some reason, the CPF number is rescinded (which can happen if someone does not pay tax in Brazil for more than a year, for example if you are abroad, without explanation). For Brazilians, losing these documents or having them stolen or used in illicit activities might represent a true nightmare for most daily activities involving either relationships with the state or with private companies. These documents are essential for everyday life and social inclusion yet, these identification interactions could result in being arrested and accused for crimes committed in places where the person concerned has never been. This may threaten the true identity of the person in psychological terms in the most extreme cases of identification fraud.

\footnotetext{
${ }^{9}$ Interview with Delegado Romulo Berredo of the Policia Federal, Brasilia, February 2009; reinforced by an interview with Subchefe of the Rio de Janeiro Policia Civil, Rio de Janeiro, April 2009.

10 ibid.

${ }^{11}$ http://www.mds.gov.br/bolsafamilia/observatorio/apresentacao.
} 
The case of Carlos da Silva has not reached these extremes yet, but serves to illustrate the complex situation of having so many identification systems running together and being used widespread without any concern for personal data and privacy issues. Yet, now as a result of the combination of the proliferation of identification systems, the requirement for many of these multiple forms of ID to be used in everyday transactions and the lack of data protection, Carlos has to combine identification interactions with a form of self-surveillance. There is a fundamental insecurity about his identification, and therefore his everyday life. There is caring or repressive government surveillance here to assist - and in fact, even being part of a police investigation, as the story showed, might have meant a worse outcome in terms of the relationship with private entities which surveil the financial profiles of citizens, and who might well be more important to the life chances of Carlos da Silva than the state. He therefore chooses a mild form of exclusion (from the formal mechanisms of the legal system), however insecure this makes him feel, as protection not from the state but from the effects of the circulation of his identification numbers (or perhaps, he suspects, even copies of this tokens of identification) amongst criminals.

Carlos da Silva is a middle class professional however, and as we have seen, many people who live in poor communities or in the informal housing of the favelas, and who are involved in the shadow economy do not even have the identification tokens or numbers which he has, in particular a CPF number, which is a severe obstacle to social inclusion. The PBF, which intends to remedy some of these problems, combines the provision of benefits and a particular number and token of identification with surveillance practices. The PBF card, as a token, is designed to generate a sense of inclusion-hence the patriotic colours - and this is reinforced by the pictures of happy smiling PBF cardholders on government websites. This is clearly to avoid the possibility of the PBF card becoming a stigma, like so many other markers of entitlement to state support.

The surveillance occurs through the monitoring of school attendance by childrenfor which there is a particular sub-program of the PBF called Projeto Presença (Project Presence) with its own reporting systems ${ }^{12}$ - and epidemiology and surveillance of nutrition through the Ministry of Health, and there is lot of household information collected to determine 'need'. John Gilliom (2001) showed how much Federal assistance programs in the USA could impact negatively upon the lives of claimants, particularly women, in the Appalachian region, and revealed the everyday forms of resistance. However, from interviews with Community Association leaders in Rio de Janeiro, it seems that where PBF is operating effectively (and it is not doing so everywhere), the combination of school attendance with economic assistance is seen as a double bonus, not as a form of control. ${ }^{13}$ Attendance at school provides not only an education which might keep kids out of gangs or early pregnancy, but also a record with the state - in other words, it builds up those early forms of identification which will lead to the obtaining of a CPF and 'normal' citizenship.

\footnotetext{
12 http://frequenciaescolarpbf.mec.gov.br/presenca/controller/login/efetuarLogin.php.

${ }^{13}$ Interviews with Elisa, Leader of the Associação dos Moradores of Morro dos Prazeres, and Sonia, member of the committee of the Associação dos Moradores of Santa Marta. Members of community organisations in Tavares de Bastos noted that PBF had not really penetrated their community effectively yet.
} 


\section{From a "vast array of papers" towards a new integrated ID system}

Now, in the name of security and "para integrar os bancos de dados de diversos órgãos dos sistemas de identificação do Brasil" (to integrate the databases of the diverse organisations of identification systems in Brazil), the Ministry of Justice is proposing to merge some of these ${ }^{14}$ - the RG, CPF, Driving License and Electoral Registration ${ }^{15}$-, into a new, smart, Registro de Identidade Civil (RIC) card based on a unique number (Fig. 6). The new ID card has been a long time coming. It originated well before the post-9/11 panic and surveillance surge, with Federal Law 9454/1997, and was originally conceived of largely in terms of a database integration project. However it was not funded until 2004. The process of enrolment and issuing of the new cards was due to have started in January 2009 in the poorer and remote northern and north-eastern states, with the aims of registering 20 million people per year, which would lead to the entire population being covered by 2017 .

According to the Ministry of Justice (see note 10), the system will lead to " $a$ identificação civil no Brasil ainda mais eficiente" ("a much more efficient civil identification system in Brazil") and "estabelecer uma relação de unicidade entre o cidadão e seu documento" ("establish a relationship of uniqueness between the citizen and their document").

It is notably that the plan will also create a nationwide fingerprint database, something that the state has so far not created even for law enforcement as in many other advanced democracies (Cole 2001). Given the complete lack of laws on datasharing and data-protection, it seems highly likely that this database will be accessible to the police services. Unlike in the UK however, the enterprise is not conceptualised in a punitive way-there is no indication of punishment for noncompliance with the issuing of the cards or provision of person data.

The whole basis on which identity cards and database issues is being considered in Brazil is entirely different from other contemporary proposed introductions, particularly that of the UK. Interviews with Brazilian community leaders, human rights advocates ${ }^{16}$ and the police demonstrated widespread support across the political spectrum in favour of the new system. For almost all Brazilians interviewed or questioned more casually, the new ID cards were not seen as a form of control or intrusion by the state but a guarantee against the anonymity that would allow abuses by the state or indeed by other malicious persons. Some felt this attitude was so strong that it was something fundamental to Brazilian thinking; for example, it was referred to as a 'cultural characteristic' of Brazilians by Delegado Romulo Berredo of the Federal Police.

A new unified identity card then provides a metaphysical and material kind of certainty and stability. For Brazil, the legacy of the twentieth century with its rapidly

\footnotetext{
$\overline{14}$ http://www.mj.gov.br/data/Pages/MJ4E0605EDITEMIDE68116000F5D4DEEA482928F77460 DEBPTBRNN.htm.

15 http://www.mj.gov.br/main.asp?ViewID=\%7B4E0605ED-A923-47D1-8313-91B5B639C26E\%7D\& params $=$ itemID=\%7B5C2648E5-1100-4289-A22E-40A71BCAE5A8\%7D;\&UIPartUID=\%7B2218FAF95230-431C-A9E3-E780D3E67DFE\%7D.

${ }^{16}$ Interviews with Artigo $1^{\circ}$ and Projeto Pro Bono, São Paulo, February 2009.
} 


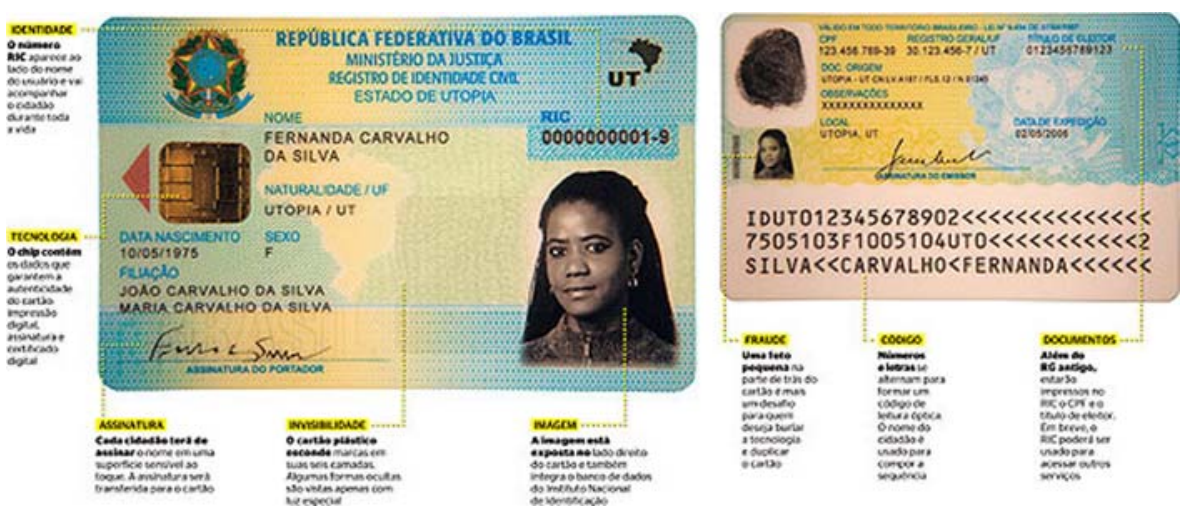

Fig. 62009 Government mock-up of the new Brazilian ID card

changing mixture of dictatorship, military rule and more or less democratic republics, was not so much a nightmare of knowledge and order in the manner of the 'surveillance state' of East Germany (see Garton Ash 1998) but of corrupt, chaotic and arbitrary rule, where politics, policies and people appeared and disappeared rapidly and where nothing seemed fixed. Even the last period of military rule that ended in 1985 was not a unified system of totalitarian control but was characterised by periods of both intense and seemingly arbitrary brutality and populist developmental policies. And indeed General Vargas's populist rule from 1930, particularly the Estado Novo dictatorship from 1937-1945, when many of what Brodwyn Fischer (2008) calls the "vast array of papers" that were the precursors of the current system were first introduced, was far from being comparable to Nazism or Fascism. Vargas in fact extended the electoral franchise and introduced many programs for social inclusion and citizenship.

However, whatever the intent, James Holston (2008) argues that the Estado Novo relied extensively on superficial signs and spectacles of citizenship rather than genuine inclusion. This analysis is largely supported in a contemporaneous work by Fischer, who argues that the Vargas regime "forged an idealized form of Brazilian citizenship, creating a wide array of political, social and economic rights that gave working people hope in the possibilities of law and politics" (2008: 2). However the citizenship reforms, like the original citizenship, were inequitable in practice for several reasons. Firstly, the existence of new documents created a powerful set of bureaucratic intermediaries who were (and are) able to create arbitrary obstacles to the obtaining, contents and use of the documents. As Fischer comments, "each of these documents was a passport to a specific realm of rights; and each of these documents of Brazilian citizenship had its paper signifier and without it none could enter" (ibid: 120). Secondly, the process encouraged corruption in order to overcome these obstacles, leading "the very poor to depend heavily on patrons and shady intermediaries or to act extra-legally_presenting false witnesses and papers, lying about birth dates, bribing notaries - in order to secure their legal rights" (ibid: 125).

Thirdly, the 1934 CLT created a system of labour-based identification that divided rather than united. This was because of the moral element-essentially a worker's 
card "became a powerful symbol of righteous citizenship... outside of the workplace" (ibid: 128). In some ways, the CPF card still maintains this distinction, and although the inclusivity offered by the PBF goes some way to challenging this, Brazilian citizenship has always been one which from its beginning has been almost ubiquitous but never something which conferred equal rights. Holston (2008) refers to this as 'differentiated citizenship'. But it was actually after the Estado Novo, that this differentiation led to increasing association of the possession of identification papers with the psychological 'nature' of their bearers - and correspondingly, the nature of those who did not possess them. By the period of renewed republican democracy from 1950-1964, the police would commonly take the complaints of those with papers more seriously, they were seen as having 'good character' and those without would be ignored or even subjected to arbitrary violence (Fischer 2008). In other words, the absence of a worker's card, or eventually any identifying papers, became associated with a lack of personhood. The non-identifiable were non-persons, non-humans, and could therefore be 'disappeared' more easily. Such disappearances only became a daily reality in the military regime of 1964-1988 and the advent of both state and private death squads, however they continue to operate today under the euphemistic moniker of autodefesas communitárias ("community self-defence organisations', or ADCs).

This brief account shows that arguments about the inclusiveness of the Estado Novo identification regime can be taken too far (and Vargas was hardly a progressive democrat), but it does point out the danger of making a simplistic equation of the introduction of identification systems with fascism or authoritarianism as if this in itself is enough to explain the perceived moral wrongness of state identification. It has been almost a commonplace to argue that Fichte's police state might be realised in the post-9/11 climate, with tendencies towards an increasingly totalitarian identification discourse (e.g. Robertson 2006). However even Fichte's strong vision of the ideal police state was also framed within an enlightenment discourse of 'rights.' One particular right now often forgotten in analysis of identification in the global north is the right to registration of identity itself. Simon Szreter (2007: 67) provides a powerful reminder of this progressive understanding of the relationship of the state and identity, reminding us that such a right is at the heart of the UN Convention on the Rights of the Child, and arguing that:

Without the legally sanctioned, secure, and practically available capacity to prove one's identity, the political rhetoric of human rights, and the academic discourse of entitlements, functionings, and capabilities... remains at best, a set of ideals and aspirations for the world's anonymous poor

Based on a re-analysis of the history of British welfare regimes from the Sixteenth Century onwards, he makes a strong claim that "registration can... be a multi-faceted institutional mechanism for simultaneously promoting economic growth, population health, and welfare" (ibid: 79), and that arguments that registration systems facilitate totalitarianism and genocide are as facile as arguing that railway systems facilitate such things because both were used by the Nazis.

Thus in Brazil, the introduction of a unitary identification system is seen not so much evidence of a scheme to control individuals but a way to ward off chaos, the dangerous anonymity that can lead to total disappearance, and increase certainty and 
ultimately personhood. It is part of a loose and ever-changing bundle of elements associated with the improvement of both governance and the human condition-but generally not with control. In many ways, this contains elements of 'magical thinking': a universal ID will not stop bullets. But it does provide a way in which the differentiations of past conceptions of differentiated citizenship progressively disappear, and are replaced instead by the confirmation of a positive identity (in the wider sense of the word). Fischer (2008) quotes an old woman she encountered in a Rio favela in the mid-1990s who said that with ID papers, she was finally able to "feel like a person." Such sentiments were not uncommon with the community leaders interviewed in 2009 when asked about the RIC system. In fact, in none of the interviews with poor and working class contacts, including favela residents, did any interviewee express any negative sentiments about the proposed new ID card. It was only amongst the educated middle-class interviewees, and generally those with international connections, that any concern about state surveillance or control were expressed.

The danger, indeed the inevitability, as far as many interviewees were concerned was not control, but the incompetence of the state. "It will never happen" was a commonly stated belief about the new RIC ID system, or else it would get halfway and be cancelled by a new government. Interviewees also questioned whether the new card would really replace other tokens of identification or simply add another layer. Certainly the CPF card will have the new unique RIC number on it, at least until the entire enrolment program is complete and all RIC cards issued. In addition, the number of identification systems continues to proliferate rather than diminish - for example, plans were recently announced for a special ID card for football fans, while some football clubs are already registering supporters in stadiums to facilitate identification in case of violence. Not all parts of the state bureaucratic machine appear to share the faith in reduced but clearer points of contact between state and citizen.

And of course, people were worried about criminality and corruption. Whilst the Ministry of Justice claims it will be very safe, the new RIC will have many of the same problems as new smart ID systems everywhere else, in that chips can be cloned or even reprogrammed by determined fraudsters with relatively cheap equipment. On the other hand, however, at the very least it might stop Brazilian citizens carrying around multiple documents that list almost everything any thieves and fraudsters need and can access without any sophisticated equipment. For someone like Carlos da Silva, the need to prove that he is who he is would have been even harder if it had been his unique and trusted and supposedly secure new RIC card that had been hacked or cloned or copied. The effects could be far more devastating if, he hopes, rather less common.

The question remains however, whether with the adoption of global standards of identification will come new 'global' norms of suspicion, policing and the attempts to fix populations in categories. Certainly this is not new in Brazil: the colonial administration prior to independence had minutely detailed racial categories which were maintained until long after independence (Holston 2008), and, as we have seen, the Novo Estado attempted a new set of categorisations based around 'labour' (Perlmann 1976; Fischer 2008; Holston 2008). Yet, it can be argued that the trend in contemporary Brazil is against this under the present government. At the same time, it is well known to both Brazilian jurists and government alike that there is a huge gap between the legislation and practical means of identification, and what 
happens to identity in the daily life; or that the traditional juridical models used in the country are insufficient to deal with the complex and fragmented aspects of contemporary Brazilian society (Amaral 2002). The nature of identification within the Brazilian justice system is unfortunately a topic for which we do not have space in this paper.

However significant problems with the view of the new Brazilian ID scheme as inclusionary remain. Szreter (2007) recognises some of these, when he considers what are the implications if the construction of a national system of registration and identification is both essential for development and carried out in the interests of the citizen. These include: the recognition of the ownership of the information by the citizen; the existence of a democratic and strong civil society, and ideally the operation of such systems by independent bodies overseen by the UN, or run by UN-recognised rules. For Brazil such things are problematic, particularly the absence of any system of oversight of state collection, storage and use of personal data. There also remain problems with Brazilian democracy: it may be that surveillance infrastructure has no necessary connection to totalitarianism, but it is the tendency to rapid and violent change that is of more concern in Brazil, as well as its ongoing lack of real depth of civil society organisations.

It is debatable, in wider the context of contemporary capitalism, whether 'inclusion' and 'exclusion' are the most appropriate categories for assessing identification and surveillance. Luc Boltanski and Eve Chiapello (2005) have developed the Deleuzian notion of 'encounter' to argue that the key categories are those of connection and disconnection, and more importantly the ability to make and break connections or, alternatively, have them more or less eternally determined. Through this lens it may be that new schemes of state identification might not empower the 'excluded' by creating a greater sense of inclusion, but in fact add another layer of external determination to their connectedness, thereby rendering them more powerless still. This needs further investigation.

Lula's government may be attempting to bring justice, probity, efficiency and order to a previously unjust, corrupt, inefficient and disordered state. However, if Brazil is to establish an inclusive or empowering system of identification and citizenship, however one defines it, it would need to have accountability built in. It simply has no such accountability at present, and the problems of this absence will become more apparent as its information society, and its surveillance society, develops. One should not rule out the successful bootstrapping of one 'goodenough' reform on top of another, however it may well be that any hope that the new unitary identification scheme might provide more meaningful personhood will be as fleeting as many previous utopian dreams.

Acknowledgements This research was made possible through the grant of a Research Fellowship to David Murakami Wood from the UK Economic and Social Research Council (ESRC), entitled Cultures of Urban Surveillance, and a temporary Visiting Professor position from the Pontifical Catholic University of Paraná (PUCPR), in Curitiba. We wish to thank the ESRC and PUCPR for their support. We would also like to thank our anonymous referees for their constructive and helpful comments and suggestions.

Open Access This article is distributed under the terms of the Creative Commons Attribution Noncommercial License which permits any noncommercial use, distribution, and reproduction in any medium, provided the original author(s) and source are credited. 


\section{References}

Amaral F. O direito civil na pós-modernidade. Rev Bras Direito Comp. 2002;21:3-20.

Bauman Z. Identity. Cambridge: Polity; 2004.

Bennett CJ, Lyon D, editors. Playing the identity card: surveillance, security and identification regimes in global perspective. London: Routledge; 2008.

Boltanski L, Chiapello E. The new spirit of capitalism. New York: Verso; 2005.

Caeton D. The cultural phenomenon of identity theft and the domestication of the world wide web. Bull Sci Tech. 2007;27(1):11-23.

Caplan J. 2001, “This or that particular person.” Protocols of Identification in Nineteenth Century Europe. In: Caplan and Torpey, editors. p. 49-66.

Caplan J, Torpey J, editors. Documenting individual identity: the development of state practices in the modern world. Princeton: Princeton University Press; 2001.

Cole S. Suspect identities: a history of fingerprinting and criminal identification. Cambridge: Harvard University Press; 2001.

Dandeker C. Surveillance, power and modernity. Cambridge: Polity; 1990.

Deleuze G. Postscriptum sûr les sociétés de contrôle. L'autre Journal. 1990.

Doneda D. Considerações iniciais sobre os bancos de dados informatizados e o direito à privacidade. In: Tepedino G, editor. Problemas de direito civil-constitucional. Rio de Janeiro: Renovar; 2000.

Doneda D. Os direitos da personalidade no Código Civil. In: Tepedino G, editor. A parte geral do novo Código Civil: Estudos na perspectiva civil-constitucional. 3a edição. Rio de Janeiro: Renovar; 2006 a.

Doneda D. Pessoa e privacidade na sociedade da informação, Da privacidade à proteção de dados pessoais. Rio de Janeiro: Renovar; 2006b.

Fischer B. A poverty of rights: citizenship and inequality in Twentieth-Century Rio de Janeiro. Stanford: Stanford University Press; 2008.

Garton Ash T. The file: a personal history. New York: Vintage; 1998.

Gilliom J. Overseers of the poor. Chicago: University of Chicago Press; 2001.

Groebner V. Who are you? Identification and deception in early modern Europe. New York: Zone; 2007.

Holston J. Insurgent citizenship: disjunctions of democracy and modernity in Brazil. Princeton: Princeton University Press; 2008.

Lyon D. Surveillance society: monitoring everyday life. Buckingham: Open University Press; 2001.

Lyon D. Surveillance studies: an overview. Cambridge: Polity; 2007.

Lyon D. Identifying citizens: ID cards as surveillance. Cambridge: Polity; 2009.

Marron D. Alter reality: governing the risk of identity theft. Br J Criminol. 2008;48:20-38.

Monahan T. Identity theft vulnerability: neoliberal governance through crime. Theor Criminol. 2009;13 (2):155-76.

Murakami Wood D ed., Kirstie Ball, David Lyon, Clive Norris and Charles Raab. A Report on the Surveillance Society. Wilmslow: ICO.

Murakami Wood D. The Surveillance Society: questions of history, place and culture. Eur J Crim. 2009;44 (2).

Murakami Wood D, David DL, Abe K. Surveillance in urban Japan: a critical introduction. Urban Stud. 2007;44(3):551-68.

Perlmann JE. The myth of marginality: urban poverty and politics in Rio de Janeiro. Berkeley: University of California Press; 1976.

Robertson R. The increasing monopolization of identity by the state: the case of the UK and the US. Nationalism Ethn Polit. 2006;12(3):373-87.

Rose N. Powers of freedom. Cambridge: Cambridge University Press; 1999.

Scott JC. Seeing like a state: how certain schemes to improve the human condition have failed. New Haven: Yale University Press; 1998.

Szreter S. The right of registration: development, identity registration, and social security —a historical perspective. World Dev. 2007;35(1):67-86.

Torpey J. The invention of the passport: surveillance, citizensip and the state. Cambridge: Cambridge University Press; 2000.

Whitson J, Haggerty KD. Identity theft and the care of the virtual self. Econ Soc. 2008;37(4):571-93. 